\title{
MODEL PERTAHANAN JEPANG DI KABUPATEN LUMAJANG DAN JEMBER, JAWA TIMUR: TIPOLOGI DAN ARAH SASARAN
}

\author{
JAPANESE DEFENSE MODEL \\ IN LUMAJANG AND JEMBER, EAST JAVA: \\ TYPOLOGY AND DIRECTION TARGET
}

\author{
Muhammad Chawari \\ Balai Arkeologi Yogyakarta \\ Email : mchawari@yahoo.com
}

\begin{abstract}
This paper is based on research conducted by Yogyakarta Archaeological Center in 2013 with the theme of the Japanese Defense Facilities In The World War II in Lumajang and Jember. The research is an effort to disclose the typology of Japanese defense facilities well as their coverage in both locations. At both locations have been identified 43 objects from the era of Japanese occupation, consisted of bunker (40 objects), cave (2 objects), and water tank ( 1 object). Among them, 38 objects commanded the sea traffic, 4 objects commanded land routes, and 1 object is unknown.
\end{abstract}

Keywords: Typology, Coverage, and Japanese Defense System.

\begin{abstract}
ABSTRAK
Karya tulis ini didasarkan atas hasil penelitian yang dilakukan Balai Arkeologi Yogyakarta pada tahun 2013 dengan tema Sarana Pertahanan Jepang Pada Masa Perang Dunia II di Kabupaten Lumajang dan Jember. Melalui penelitian tersebut dapat diketahui tipe dan jangkauan sarana pertahanan Jepang yang ada di kedua lokasi tersebut. Di kedua lokasi tersebut telah diidentifikasi 43 objek tinggalan kolonial Jepang. Ke-43 objek tersebut terdiri atas bungker (40 objek), gua ( 2 objek), dan tandon air (1 objek). Seluruh objek tersebut sasarannya adalah lalu lintas laut (38 objek), lalu lintas darat (4 objek), dan tanpa arah yang jelas (1 objek).
\end{abstract}

Kata kunci: Tipologi, Arah Jangkauan, dan Pertahanan Jepang.

Tanggal masuk : 04 Maret 2015

Tanggal diterima : 15 Mei 2015 


\section{LATAR BELAKANG DAN PERMASALAHAN}

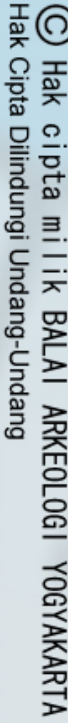

Beberapa tahun menjelang kemerdekaan, di banyak wilayah di Indonesia bermunculan hasil karya cipta orang-orang Jepang, khususnya budaya fisik. Budaya fisik dalam konteks ini adalah bungker. Keberadaan bungker-bungker Jepang di Indonesia erat kaitannya dengan usaha Jepang untuk membangun suatu imperium di Asia. Dalam usahanya tersebut, Jepang telah meletuskan perang Pasifik. Perang ini berhubungan erat dengan ambisi Jepang untuk memiliki bahan-bahan industri yang dapat diperoleh di negara-negara yang terletak di sebelah selatan Jepang, termasuk Indonesia (Kartodirjo dkk, 1976: 1).

Jauh sebelum kedatangan orang-orang Jepang, daerah Lumajang maupun Jember sudah tampil dalam panggung sejarah kebudayaan di Indonesia. Tampilnya Lumajang dan Jember terutama pada masa Indonesia klasik yaitu masa pengaruh budaya HinduBudha. Daerah Lumajang dikenal memiliki tinggalan arkeologi yang cukup banyak dan beragam serta sebagai kawasan penting pada masa Majapahit (Priswanto, 2015: i). Peninggalan dari masa klasik yang ada di Lumajang antara lain dapat dilihat pada keberadaan Situs Biting dan Candi Kedungsari. Akan tetapi, hingga saat ini penelitian tentang tinggalan budaya kolonial di wilayah tersebut belum dilakukan secara intensif, dengan demikian temuan berupa bungker Jepang dapat mengisi kekosongan hasil penelitian budaya kolonial di wilayah Lumajang.

Berdasarkan atas latar belakang diatas maka dirumuskan beberapa permasalahan sebagai berikut:

- Apakah Sarana Pertahanan Jepang dari masa Perang Dunia ke II juga terdapat di wilayah Kabupaten Lumajang dan Kabupaten Jember, Propinsi Jawa Timur.

- Jika Sarana Pertahanan Jepang tersebut juga terdapat di Kabupaten Lumajang dan Kabupaten Jember, Propinsi Jawa Timur, bagaimana pola persebaran dan tipologinya.

\section{METODE PENELITIAN}

Metode penelitian dalam karya tulis ini bersifat deskriptif eksplanatif dengan penalaran induktif. Untuk menjelaskan hal-hal yang berkaitan dengan permasalahan penelitian, yaitu pemahaman mengenai sarana pertahanan Jepang pada masa PD II, beberapa tahapan yang dilakukan adalah:

1. Pengumpulan data dilakukan melalui studi literatur hasil penelitian terdahulu, dan informasi masyarakat lokal yang kemudian ditindaklanjuti dengan kegiatan survei lapangan. Pengumpulan data melalui survei permukaan dilakukan pada bungker Jepang dari masa PD II.

2. Analisis data yang dilakukan mencakup analisis data arkeologis dan analisis data sejarah, dengan penekanan pada aspek fungsional dan aspek kesejarahan. Tujuannya untuk merekonstruksi sarana pertahanan Jepang pada masa PD II.

3. Sintesis dilakukan dengan menyimpulkan hasil penelitian yang bertujuan untuk merekonstruksi sarana 
pertahanan Jepang pada masa PD II.

\section{Keadaan dan Kondisi Tinggalan Kolonial Jepang \\ 1. Kabupaten Lumajang}

Nama Lumajang telah disebutkan dalam Nagarakretagama, yaitu salah satu lokasi yang dikunjungi oleh Hayam Wuruk. Nama Lumajang bahkan telah disebutkan dalam prasasti yang diterbitkan sebelum masa Hayam Wuruk, yaitu prasasti Mula Malurung yang berangka tahun 1117 Saka atau 1255 Masehi. Prasasti tersebut menyebutkan nama Lamajang untuk nama Lumajang sekarang. Data tertulis lainnya yang menyebut nama Lumajang adalah naskah Pararaton, Kidung Harsa Wijaya, Bujangga Manik, Serat Babad Tanah Jawi, dan Serat Kanda (Rangkuti, 2003: 1).

Dewasa ini Kabupaten Lumajang terdiri atas 18 kecamatan. Dari 18 kecamatan tersebut, sisa-sisa kejayaan masa pendudukan Jepang ditemukan di 4 kecamatan, yaitu Kecamatan Yosowilangun, Tempeh, Pasirian, dan Tempursari. Yosowilangun merupakan kecamatan yang terletak di pojok tenggara Lumajang yang berbatasan dengan Kabupaten Jember di sebelah timur, Kecamatan Kunir di sebelah barat, Kecamatan Tekung dan Rowokangkung di sebelah utara, serta Laut Selatan di sebelah selatan. Secara umum areal di sebelah selatan merupakan pantai sedangkan di sebelah utara merupakan permukiman pedesaan yang tergolong padat. Tempeh merupakan kecamatan yang terletak di bagian selatan Lumajang yang berbatasan dengan Kecamatan Kunir di sebelah timur, Kecamatan Pasirian di sebelah barat, Kecamatan Sumbersuko di sebelah utara, serta Laut Selatan di sebelah selatan. Secara umum areal di sebelah selatan merupakan pantai yang disebelah utaranya merupakan sawah dan ladang. Di kawasan ini terdapat permukiman pedesaan yang tidak padat dan cenderung sedikit. Kemudian Pasirian merupakan kecamatan yang terletak di bagian selatan Lumajang yang berbatasan dengan Kecamatan Tempeh di sebelah timur, Kecamatan Tempursari di sebelah barat, Kecamatan Pronojiwo di sebelah utara, serta Laut Selatan di sebelah selatan. Secara umum areal di sebelah selatan merupakan pantai dengan perbukitan dan sekit permukiman pedesaan di sekitarnya. Adapun Tempursari merupakan kecamatan yang terletak di bagian selatan Lumajang yang berbatasan dengan Kecamatan Pasirian di sebelah timur, Kabupaten Malang di sebelah barat, Kecamatan Pronojiwo di sebelah utara, serta Laut Selatan di sebelah selatan. Secara umum areal di sebelah selatan merupakan pantai sedangkan di sebelah utara merupakan perbukitan dengan permukiman pedesaan yang tergolong tidak padat.

\section{a. Kecamatan Yosowilangun}

Di Dusun Krajan, Desa Wotgaleh, Kecamatan Yosowilangun ditemukan delapan bungker Jepang yang 
Tabel 1. Bunker Jepang di Kecamatan Yosowilangun

\begin{tabular}{|c|c|c|c|c|c|c|c|}
\hline \multirow{2}{*}{ No. } & \multirow{2}{*}{ Nama Objek } & \multicolumn{7}{|c|}{ Deskripsi Objek } \\
\cline { 3 - 8 } & & Arah $^{*}$ & Denah $^{*}$ & Ruang & L. Bidik & Pintu & Ventilasi \\
\hline 1. & Bungker YWL-0I & Laut & PP & 2 & 2 & 2 & 2 \\
\hline 2. & Bungker YWL-02 & Laut & PP & 1 & - & 2 & 2 \\
\hline 3. & Bungker YWL-03 & Laut & BS & 1 & - & 1 & - \\
\hline 4. & Bungker YWL-04 & Laut & U & 1 & - & 2 & 2 \\
\hline 5. & Bungker YWL-05 & Laut & L & 1 & - & 1 & - \\
\hline 6. & Bungker YWL-06 & Laut & U & 1 & - & 1 & - \\
\hline 7. & Bungker YWL-07 & TL-TG & L & 1 & 2 & 1 & - \\
\hline 8. & Bungker YWL-08 & BD-BL & L & 1 & 2 & 1 & - \\
\hline
\end{tabular}

Keterangan: Arah: $\mathrm{TL}=$ Timur Laut, $\mathrm{TG}=$ Tenggara, $\mathrm{BD}=$ Barat Daya, $\mathrm{BL}=$ Barat Laut.

Denah: $P P=$ Persegi Panjang, $B S=$ Bujur Sangkar, $U=$ Seperti Huruf $U, L=$ Seperti Huruf $L$

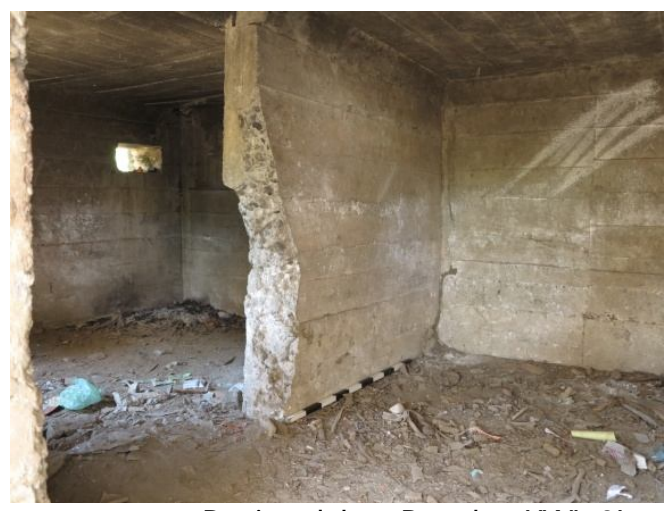

Gambar 1. Bagian dalam Bungker YWL-0l

seluruhnya dibuat dari cor semen

b. Kecamatan Tempeh

Di Dusun Parasgowang,

Desa Pandan Arum, Kecamatan

Tempeh ditemukan empat

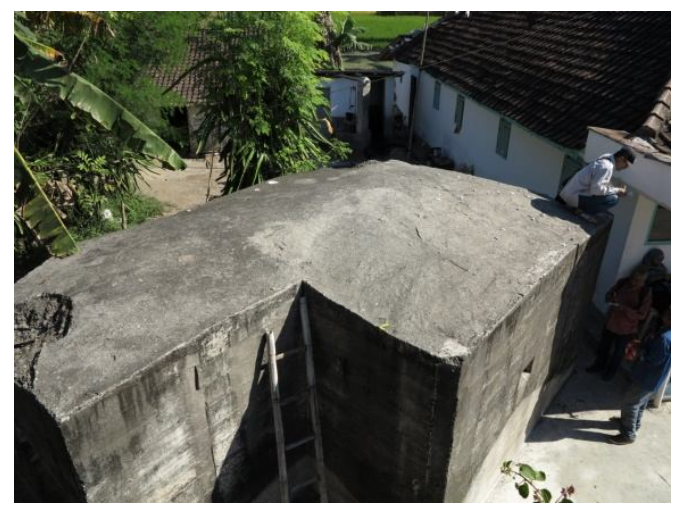

Gambar 2. Bungker YWL-08 yang berdenah seperti huruf $L$ bungker Jepang. Keempat bungker ini dibuat dari cor semen.

Tabel 2. Bunker Jepang di Kecamatan Tempeh

\begin{tabular}{|c|c|c|c|c|c|c|c|}
\hline No. & \multirow{2}{*}{ Nama Objek } & \multicolumn{6}{|c|}{ Deskripsi Objek } \\
\cline { 3 - 8 } & & Arah $^{*}$ & Denah $^{*}$ & Ruang & L. Bidik & Pintu & Ventilasi \\
\hline 1. & Bungker TMP-0I & Laut & PP & 1 & 3 & 1 & 2 \\
\hline 2. & Bungker TMP-02 & Laut & PP & 2 & 1 & 1 & 2 \\
\hline 3. & Bungker TMP-03 & Laut & PP & 3 & 1 & 1 & 1 \\
\hline 4. & Bungker TMP-04 & Laut & PP & 1 & 1 & 1 & 2 \\
\hline
\end{tabular}

Keterangan: Arah: $\mathrm{TL}=$ Timur Laut, $\mathrm{TG}=$ Tenggara, $\mathrm{BD}=$ Barat Daya, $\mathrm{BL}=$ Barat Laut. Denah: $P P=$ Persegi Panjang, $B S=$ Bujur Sangkar, $U=$ Seperti Huruf $U, L=$ Seperti Huruf $L$ 


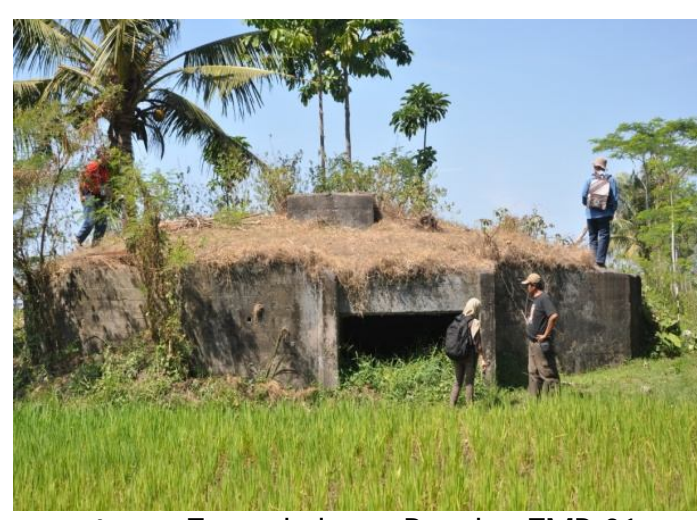

Gambar 3. Tampak depan Bungker TMP-01

\section{c. Kecamatan Pasirian}

Di Kecamatan Pasirian ditemukan delapan bungker Jepang yang terletak di 2 desa, yaitu: PSR-01 s.d. PSR-05 berada di Desa Selok Awarawar sedangkan PSR-06 s.d. PSR-08 berada di Desa Condro. Dari delapan bungker ini tujuh di

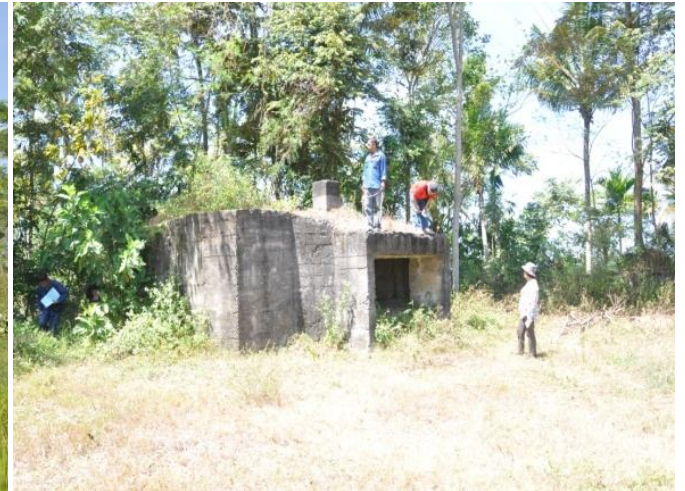

Gambar 4. Bungker TM P-02 dilihat dari samping

antaranya dibuat dari cor semen, sedangkan satu sisanya, yaitu PSR-08, pada bagian pintu dibuat dari cor semen dan pada bagian dalam merupakan gua yang dibuat dengan cara melubangi dinding bukit secara horisontal.

Tabel 3. Bunker Jepang di Kecamatan Pasirian

\begin{tabular}{|c|c|c|c|c|c|c|c|}
\hline No. & \multirow{2}{*}{ Nama Objek } & \multicolumn{7}{|c|}{ Deskripsi Objek } \\
\cline { 3 - 8 } & & Arah $^{*}$ & Denah $^{*}$ & Ruang & L. Bidik & Pintu & Ventilasi \\
\hline 1. & Bungker PSR-01 & Laut & PP & 1 & 2 & 1 & 1 \\
\hline 2. & Bungker PSR-02 & Laut & PP & 1 & 2 & 1 & 1 \\
\hline 3. & Bungker PSR-03 & Laut & PP & 1 & 2 & 1 & 1 \\
\hline 4. & Bungker PSR-04 & Laut & L & 1 & 3 & 1 & - \\
\hline 5. & Bungker PSR-05 & Laut & L & 1 & 3 & 1 & - \\
\hline 6. & Bungker PSR-06 & Jalan & TB & 1 & - & 2 & 2 \\
\hline 7. & Bungker PSR-07 & Jalan & PP & 1 & 2 & 2 & 5 \\
\hline 8. & Bungker PSR-08 & Jalan & TB & Tingkat & 2 & 3 & 5 \\
\hline
\end{tabular}

Keterangan: Arah: $\mathrm{TL}=$ Timur Laut, $\mathrm{TG}=$ Tenggara, $\mathrm{BD}=$ Barat Daya, $\mathrm{BL}=$ Barat Laut. Denah: $P P=$ Persegi Panjang, BS $=$ Bujur Sangkar, $U=$ Seperti Huruf $U, L=$ Seperti Huruf $L, T B=$ Tidak Beraturan

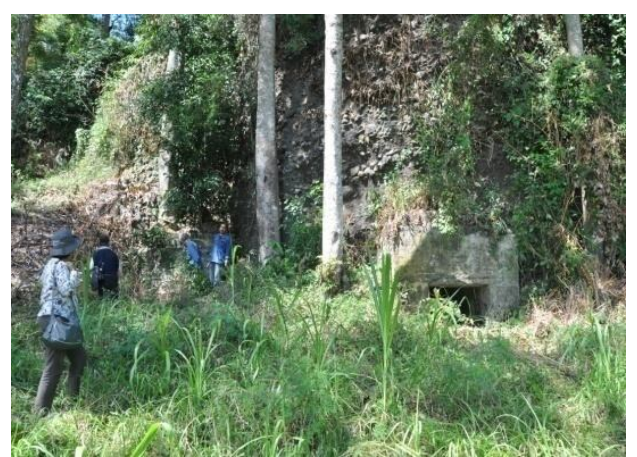

Gambar 5. Bungker PSR-06 yang terletak di sebuah bukit

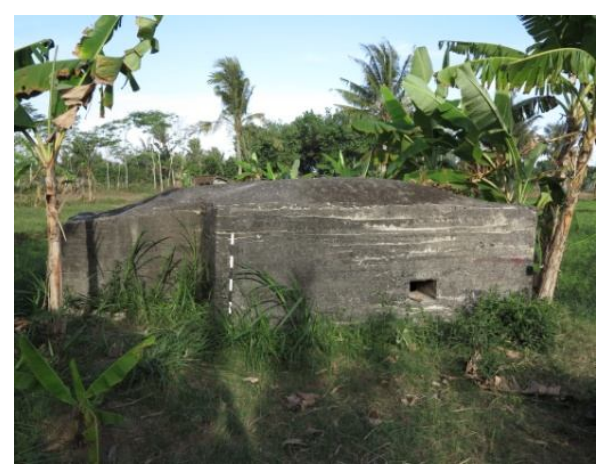

Gambar 6. Bungker PSR-05 yang terletak di persawahan 
d. Kecamatan Tempursari

Di Kecamatan Tempursari terdapat enam tinggalan Jepang yang terdiri atas dua jenis, yaitu bungker (5 objek) dan tandon air (1 objek). Keenam objek ini semuanya dibuat dari cor semen dan terletak di 2 desa, yaitu: TPR-01 s.d. TPR-02 terletak di Desa Bulurejo, sedangkan TPR-3 s.d. TPR-6 terletak di Desa Tegalrejo.

Tabel 4. Bunker Jepang di Kecamatan Tempursari

\begin{tabular}{|c|l|c|c|c|c|c|c|}
\hline No. & \multirow{2}{*}{ Nama Objek } & \multicolumn{7}{|c|}{ Deskripsi Objek } \\
\cline { 3 - 8 } & & Arah $^{\star}$ & Denah $^{*}$ & Ruang & L. Bidik & Pintu & Ventilasi \\
\hline 1. & Bungker TPR-01 & Laut & PP & 1 & - & 1 & - \\
\hline 2. & Bungker TPR-02 & Laut & PP & 2 & 1 & 2 & 3 \\
\hline 3. & Bungker TPR-03 & Laut & SL & 1 & 3 & 1 & 1 \\
\hline 4. & $\begin{array}{l}\text { Bungker (Tandon } \\
\text { Air) TPR-04 }\end{array}$ & & L & $230 \mathrm{~cm}$ & & & \\
\hline 5. & Bungker TPR-05 & Laut & PP & 1 & 2 & 1 & 2 \\
\hline 6. & Bungker TPR-06 & TL-TG & BS & 1 & 2 & 1 & 2 \\
\hline
\end{tabular}

Keterangan: Arah: $\mathrm{TL}=$ Timur Laut, $\mathrm{TG}=$ Tenggara, $\mathrm{BD}=$ Barat Daya, $\mathrm{BL}=$ Barat Laut. Denah: $P P=$ Persegi Panjang, $B S=$ Bujur Sangkar, $U=$ Seperti Huruf $U, L=$ Seperti Huruf $\mathrm{L}, \mathrm{TB}=$ Tidak Beraturan, $\mathrm{SL}=$ Setengah Lingkaran, $\mathrm{L}=$ Lingkaran

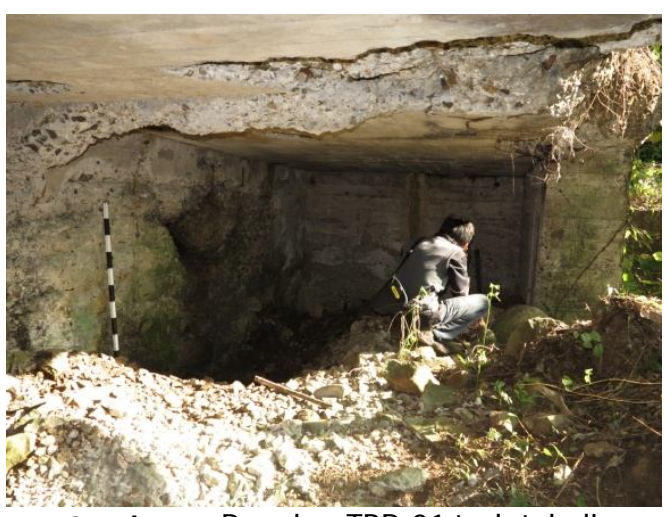

Gambar 7. Bungker TPR-01 terletak di perbukitan setempat

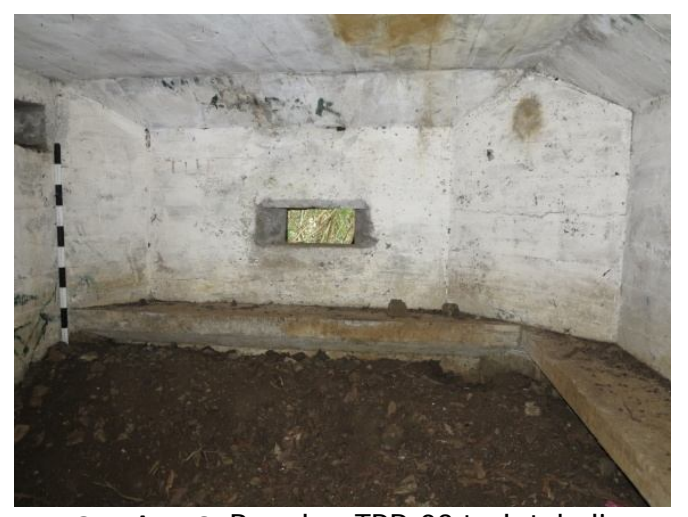

Gambar 8. Bungker TPR-03 terletak di perbukitan di pinggir laut

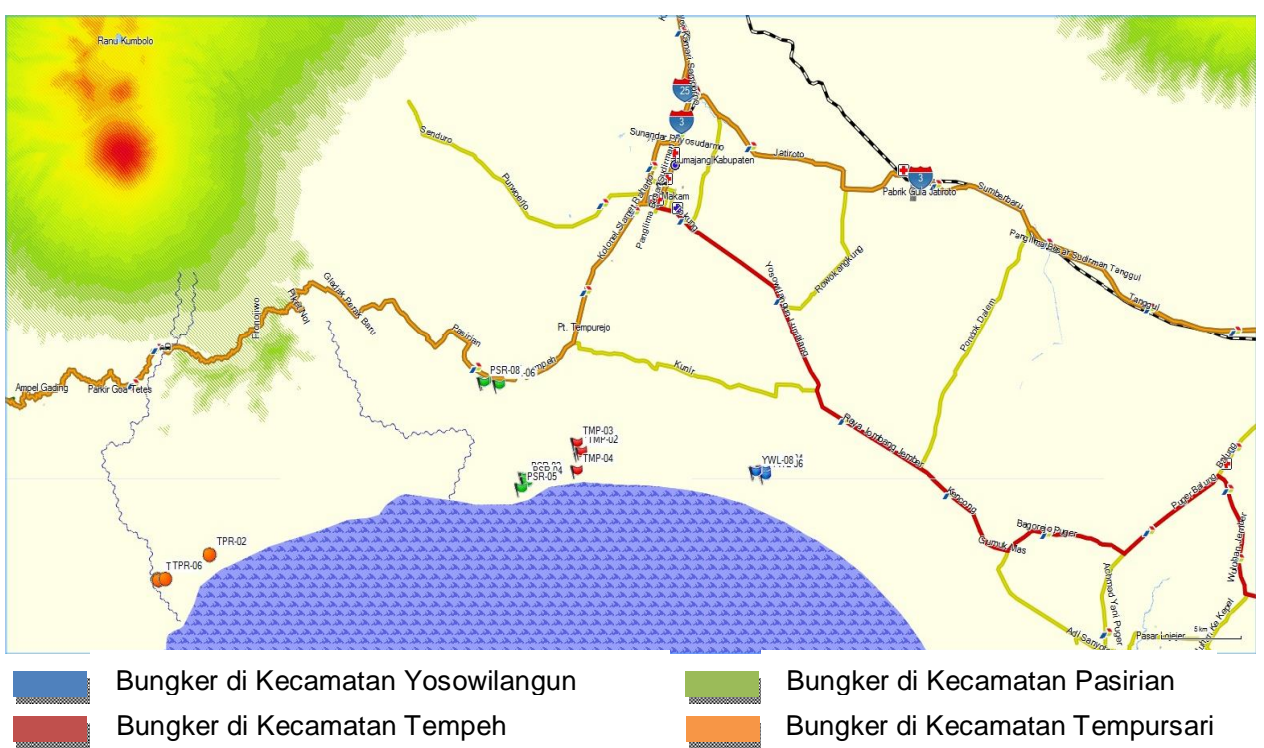

Gambar 9. Peta keletakan bungker Jepang di Kabupaten Lumajang dengan memakai program mapsource 


\section{Kabupaten Jember}

Kabupaten Jember terdiri atas 31 kecamatan. Dari 31 kecamatan tersebut, bungker Jepang ditemukan di 3 kecamatan, yaitu Kecamatan Kencong, Wuluhan, dan Ambulu. Kencong merupakan kecamatan yang terletak di bagian barat Jember yang berbatasan dengan Kabupaten Lumajang di sebelah barat, Kecamatan Gumukmas di sebelah selatan, Kecamatan Umbulsari di sebelah timur, dan Kecamatan Tanggul di sebelah utara. Secara umum areal di sebelah selatan yang berbatasan dengan Kecamatan Gumukmas merupakan areal persawahan sedangkan di sebelah utara merupakan permukiman pedesaan yang tergolong cukup padat. Kemudian Wuluhan merupakan kecamatan yang terletak di bagian selatan Jember yang berbatasan dengan laut selatan di sebelah selatan, Kecamatan Ambulu di sebelah timur, Kecamatan Balung di sebelah utara, dan Kecamatan Puger di sebelah barat. Secara umum areal di sebelah selatan merupakan pantai dengan perbukitan Watangan yang berada di bawah BKPH Wuluhan, RPH Grintingan sedangkan di sebelah utara dan timur laut merupakan permukiman pedesaan yang tergolong padat. Terakhir adalah Ambulu merupakan kecamatan yang terletak di bagian selatan Jember yang berbatasan dengan laut selatan di sebelah selatan, Kecamatan Tempurejo di sebelah timur, Kecamatan Rambipuji di sebelah utara, dan Kecamatan Wuluhan di sebelah barat. Secara umum areal di sebelah selatan merupakan pantai dengan perbukitan sedangkan di sebelah utara merupakan permukiman pedesaan.

\section{a. Kecamatan Kencong}

Di Kecamatan Kencong ditemukan 14 bungker Jepang yang terletak di 4 desa, yaitu: KCG-01 s.d. KCG-02 berada di Desa Wonorejo; KCG-03 dan KCG-11 terletak di Desa Kraton; KCG-04 s.d. KCG-09 berada di Desa Cakru; serta KCG-10 dan KCG-12 s.d. KCG-14 terletak di Desa Paseban. Ke-14 bungker ini seluruhnya dibuat dari cor semen. 
Tabel 5. Bunker Jepang di Kecamatan Kencong

\begin{tabular}{|c|c|c|c|c|c|c|c|}
\hline No. & \multirow{2}{*}{ Nama Objek } & \multicolumn{7}{|c|}{ Deskripsi Objek } \\
\cline { 3 - 8 } & & Arah $^{*}$ & Denah $^{*}$ & Ruang & L. Bidik & Pintu & Ventilasi \\
\hline 1. & Bungker KCG-01 & Laut & PP & 1 & 2 & 1 & - \\
\hline 2. & Bungker KCG-02 & Laut & BS & $?$ & $?$ & $?$ & $?$ \\
\hline 3. & Bungker KCG-03 & Jalan & BS & 1 & 1 & 1 & - \\
\hline 4. & Bungker KCG-04 & Laut & L & 2 & - & 1 & 1 \\
\hline 5. & Bungker KCG-05 & Laut & U & 1 & - & 2 & 1 \\
\hline 6. & Bungker KCG-06 & Laut & BS & 2 & - & 1 & 2 \\
\hline 7. & Bungker KCG-07 & Laut & L & 1 & 1 & 1 & 1 \\
\hline 8. & Bungker KCG-08 & Laut & U & 1 & - & 2 & 2 \\
\hline 9. & Bungker KCG-09 & Laut & BS & 1 & 3 & 1 & - \\
\hline 10. & Bungker KCG-10 & Laut & U & 1 & - & 2 & 2 \\
\hline 11. & Bungker KCG-11 & Laut & PP & 1 & 3 & 1 & - \\
\hline 12. & Bungker KCG-12 & Laut & L & 1 & - & 1 & - \\
\hline 13. & Bungker KCG-13 & Laut & L & 1 & 2 & 1 & - \\
\hline 14. & Bungker KCG-14 & Laut & U & 2 & 2 & 1 & - \\
\hline
\end{tabular}

Keterangan: Arah: $\mathrm{TL}=$ Timur Laut, $\mathrm{TG}=$ Tenggara, $\mathrm{BD}=$ Barat Daya, $\mathrm{BL}=$ Barat Laut. Denah: $P P=$ Persegi Panjang, $B S=$ Bujur Sangkar, $U=$ Seperti Huruf $U, L=$ Seperti Huruf $L, T B=$ Tidak Beraturan, $S L=$ Setengah Lingkaran, $L=$ Lingkaran

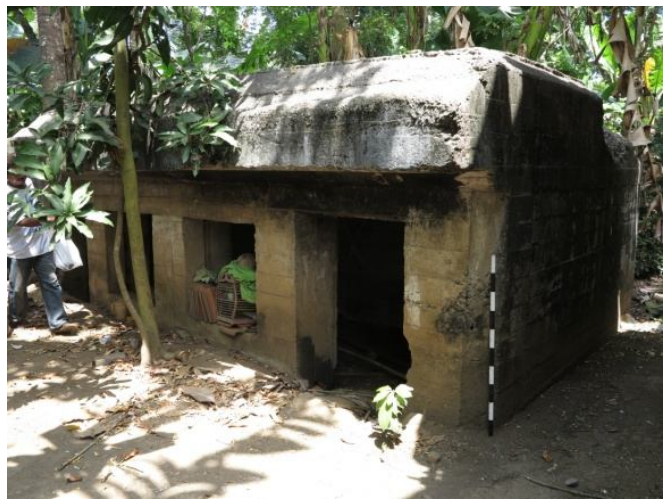

Gambar 10. Bungker KCG-14 terletak di permukiman di kawasan pantai

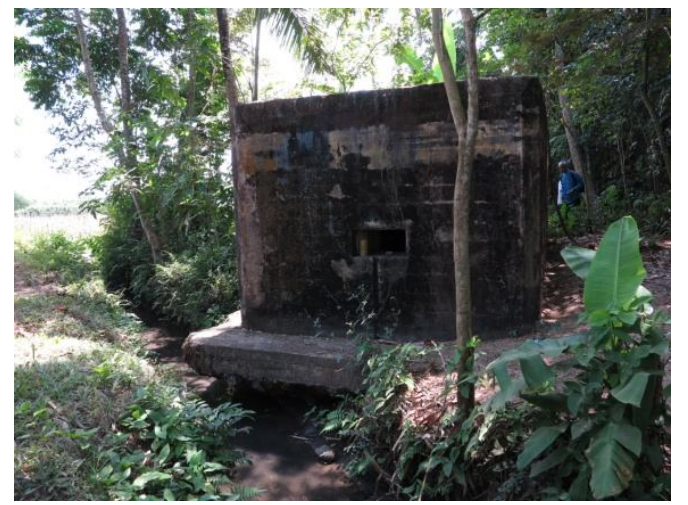

Gambar 11. Bungker KCG-13 dengan latar belakang persawahan

\section{b. Kecamatan Wuluhan}

Di Kecamatan Wuluhan ditemukan satu bungker Jepang yang terletak di Desa Lojejer.

Tabel 6. Bunker Jepang di Kecamatan Wuluhan

\begin{tabular}{|c|c|c|c|c|c|c|c|}
\hline No. & Nama Objek & \multicolumn{7}{|c|}{ Deskripsi Objek } \\
\cline { 3 - 8 } & & Arah $^{\star}$ & Denah $^{\star}$ & Ruang & L. Bidik & Pintu & Ventilasi \\
\hline 1. & Bungker WLH-01 & Laut & L & 4 & 3 & 1 & - \\
\hline
\end{tabular}

Keterangan: Arah: $\mathrm{TL}=$ Timur Laut, $\mathrm{TG}=$ Tenggara, $\mathrm{BD}=$ Barat Daya, $\mathrm{BL}=$ Barat Laut. Denah: $P P=$ Persegi Panjang, $B S=$ Bujur Sangkar, $U=$ Seperti Huruf $U, L=$ Seperti Huruf $\mathrm{L}, \mathrm{TB}=$ Tidak Beraturan, $\mathrm{SL}=$ Setengah Lingkaran, $\mathrm{L}=$ Lingkaran 


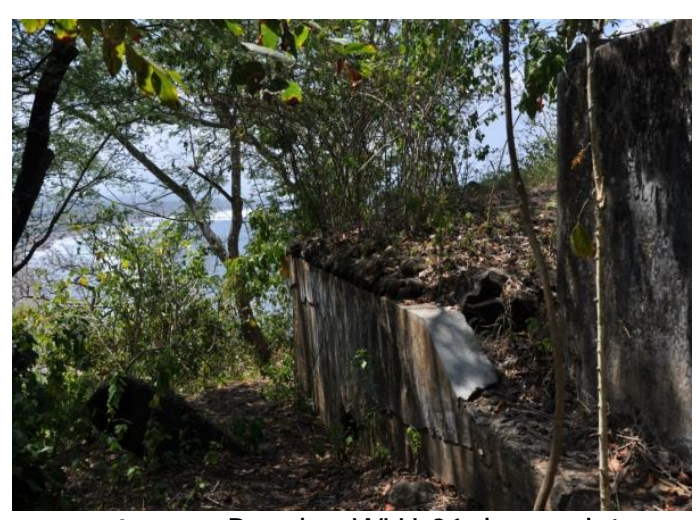

Gambar 12. Bungker WLH-01 dengan latar belakang laut selatan

\section{c. Kecamatan Ambulu}

Di Kecamatan Ambulu, tepatnya di Dusun Sumberejo, Desa Gemuling, ditemukan dua

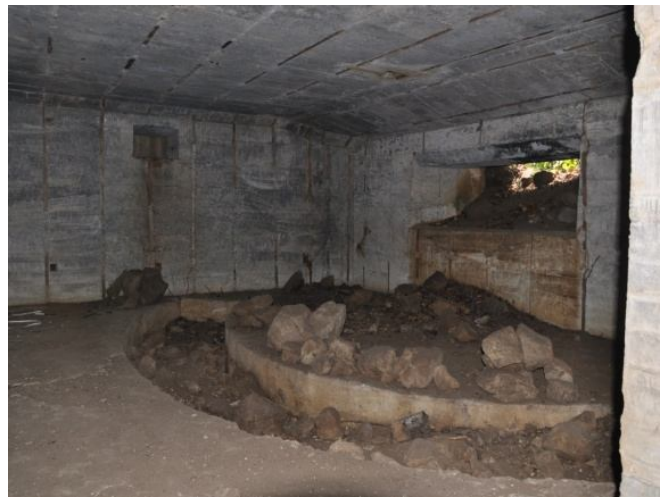

Gambar 13. Bagian dalam bungker WLH-01

bungker Jepang yang seluruhnya dibuat dari cor semen.

Tabel 7. Bunker Jepang di Kecamatan Ambulu

\begin{tabular}{|c|c|c|c|c|c|c|c|}
\hline No. & \multirow{2}{*}{ Nama Objek } & \multicolumn{7}{|c|}{ Deskripsi Objek } \\
\cline { 3 - 8 } & & Arah $^{*}$ & Denah $^{*}$ & Ruang & L. Bidik & Pintu & Ventilasi \\
\hline 1. & Bungker ABL-01 & Laut & PP & 1 & 2 & 1 & - \\
\hline 2. & Bungker ABL-02 & Laut & BS & 1 & $?$ & 1 & 2 \\
\hline
\end{tabular}

Keterangan: Arah: $\mathrm{TL}=$ Timur Laut, $\mathrm{TG}=$ Tenggara, $\mathrm{BD}=$ Barat Daya, $\mathrm{BL}=$ Barat Laut. Denah: $P P=$ Persegi Panjang, $B S=$ Bujur Sangkar, $U=$ Seperti Huruf $U, L=$ Seperti Huruf $\mathrm{L}, \mathrm{TB}=$ Tidak Beraturan, $\mathrm{SL}=$ Setengah Lingkaran, $\mathrm{L}=$ Lingkaran

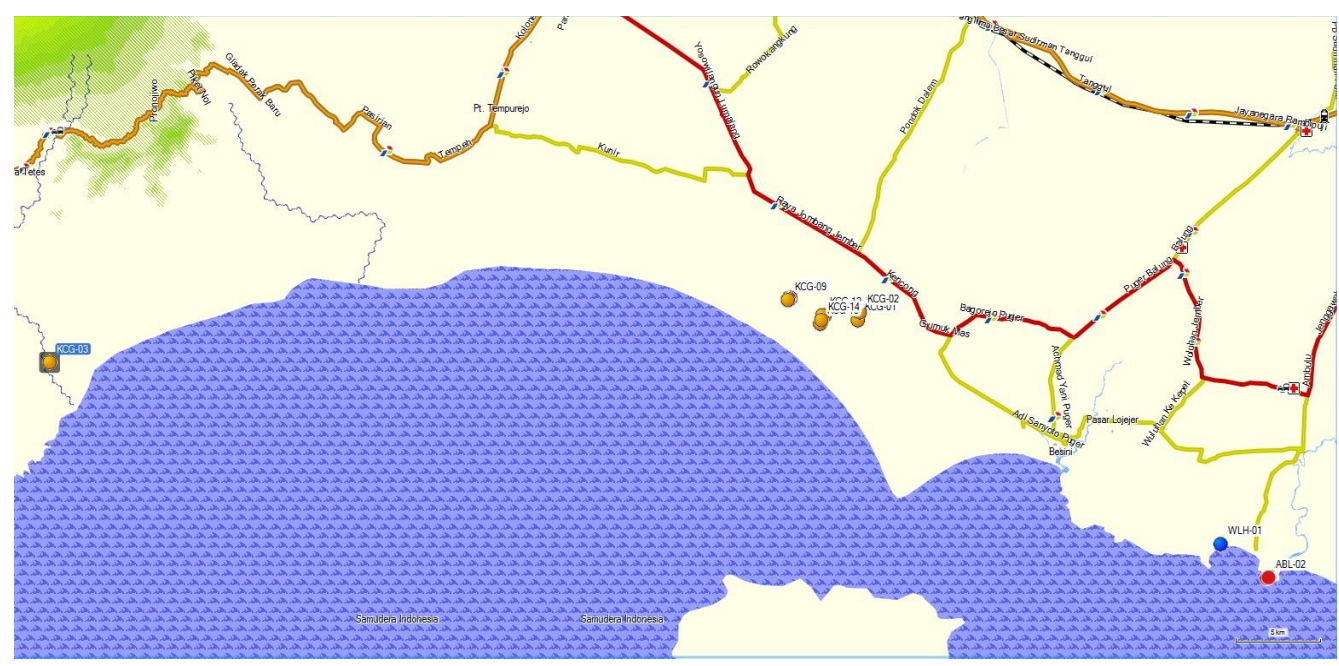

Bungker di Kecamatan Ambulu

Bungker di Kecamatan Kencong

Bungker di Kecamatan Wuluhan

Gambar 14. Peta keletakan bungker Jepang di Kabupaten Jember dengan memakai program mapsource 


\section{Klasifikasi Sarana Pertahanan Jepang}

Berdasarkan data tinggalan sisa-sisa masa pendudukan Jepang yang diperoleh di lokasi penelitian (Kabupaten Lumajang dan Jember) semuanya berjumlah 43 objek. Dari jumlah tersebut dapat dirinci, yaitu: Kabupaten Lumajang (Kecamatan Yosowilangun, Kecamatan Tempeh, Kecamatan Pasirian, dan Kecamatan Tempursari) 26 objek dan Kabupaten Jember (Kecamatan Kencong, Kecamatan Ambulu, dan Kecamatan Wuluhan) 17 objek.

Pengklasifikasian yang dimaksud dalam tulisan ini didasarkan atas dua hal, yaitu kajian berdasarkan bentuk dan kajian berdasarkan teknologi. Selain itu akan dilihat pula hubungan antara keletakan bungker dengan lingkungan di mana objek tersebut berada. Hal ini dimaksudkan agar dapat disajikan gambaran mengapa suatu bungker dibangun di suatu tempat tertentu.

Berdasarkan bentuk dan teknologinya seluruh objek yang ditemukan di Lumajang dan Jember dapat dikelompokkan menjadi tiga yaitu: kelompok bungker, kelompok tandon air, dan kelompok gua. Berdasarkan jumlahnya dari tiga kelompok tersebut kelompok bungker merupakan jumlah terbesar yaitu 40 objek, diikuti kelompok gua sejumlah 2 objek (PSR-06.dan PSR08), dan terakhir kelompok tandon air ada 1 objek (TPR-04).

Tabel 8. Klasifikasi sarana pertahanan Jepang berdasarkan bentuk dan teknologinya.

\begin{tabular}{|c|l|c|c|}
\hline No. & $\begin{array}{c}\text { Nama } \\
\text { Kelompok }\end{array}$ & Jumlah & $\%$ \\
\hline 1. & $\begin{array}{l}\text { Bungker } \\
\text { Jepang }\end{array}$ & 40 & 93,02 \\
\hline 2. & $\begin{array}{l}\text { Gua } \\
\text { Jepang }\end{array}$ & 2 & 4,65 \\
\hline
\end{tabular}

\begin{tabular}{|c|l|c|c|}
\hline 3. & Tandon air & 1 & 2,33 \\
\hline & & $\begin{array}{c}\mathbf{4 3} \\
\text { objek }\end{array}$ & $\begin{array}{c}\mathbf{1 0 0} \\
\%\end{array}$ \\
\hline
\end{tabular}

Bungker

merupakan

bangunan pertahanan yang secara teknologis seluruhnya dibuat dengan memakai cor semen. Sementara yang disebut dengan istilah gua adalah bangunan pertahanan yang secara teknologis dibuat dengan cara melubangi dinding atau tebing bukit secara horisontal. Kelompok yang termasuk gua ini di beberapa bagian menggunakan cor semen, terutama pada bagian pintu masuk. Dengan teknologi yang demikian ini maka objek tersebut memenuhi syarat disebut sebagai gua. Menurut Poerwadarminta, yang dimaksud dengan gua adalah lubang besar pada kaki gunung (Poerwadarminta, 1976: 329). Secara umum yang dimaksud dengan gua dapat dibagi menjadi dua berdasarkan terjadinya, yaitu gua alam dan gua buatan. Gua alam adalah suatu rongga di bawah tanah yang terbentuk secara alami (Anonim, 1989: 239). Mengacu pada definisi itu, maka objek-objek tersebut dapat dimasukkan dalam kategori gua, yaitu gua buatan. Gua buatan yang dimaksud dalam hal ini adalah gua buatan manusia sebagai hasil "rekayasa" bangsa Jepang menjelang pertengahan abad XX (1942 - 1945). Gua-gua tersebut dibuat dengan cara melubangi dinding bukit secara horisontal untuk mendapatkan ruang yang cukup terlindung dari pengaruh luar. Sementara sebuah bangunan lainnya disebut sebagai tandon air karena bentuknya sangat berbeda dengan bungker. Tandon air bentuknya seperti sumuran yang dicor dan fungsinya untuk mengumpulkan air (air hujan?).

Selanjutnya

perlu disampaikan bahwa keletakan 
bungker Jepang berkaitan erat dengan tujuan dibangunnya bungker tersebut. Bungker Jepang yang ada di Kabupaten Lumajang terletak di empat kecamatan yang berbeda yaitu Kecamatan Yosowilangun, Tempeh, Pasirian, dan Tempursari. Ke-4 kecamatan tersebut secara geografis terletak di pantai selatan Kabupaten Lumajang, juga Kecamatan Kunir. Demikian pula bungker Jepang yang ada di Kabupaten Jember. Di kabupaten ini bungker Jepang ditemukan di tiga kecamatan yang berbeda yaitu Kecamatan Kencong, Wuluhan, dan Ambulu. Dari ke-3 kecamatan tersebut, dua di antaranya secara geografis terletak di pantai selatan Kabupaten Jember yaitu Kecamatan Wuluhan dan Ambulu. Sedangkan Kecamatan Kencong yang berbatasan dengan Kabupaten Lumajang letaknya tidak di pinggir pantai tetapi agak masuk ke arah utara. Meskipun demikian berdasarkan keadaan geografis masuk dalam kawasan pantai. Keletakan bungker Jepang yang demikian ini (di daerah pantai) tentunya telah diperhitungkan secara matang. Hal ini terkait dengan tujuan dibangunnya bungker tersebut yaitu untuk mengawasi lalu lintas air yang melewati Laut Selatan atau Samudera Indonesia, khususnya yang ada di wilayah Kabupaten Lumajang dan Kabupaten Jember.

\section{Tipe atau Model Sarana Pertahanan Jepang}

Tinggalan masa pendudukan Jepang yang terdapat di Kabupaten Lumajang dan Jember seluruhnya berjumlah 43. Dari jumlah tersebut terdapat beberapa bentuk sesuai dengan denah bangunannya. Tipologi sarana pertahanan Jepang yang ada di Lumajang dan Jember terlihat pada tabel di bawah ini:
Tabel 9. Tipologi sarana pertahanan Jepang

\begin{tabular}{|c|l|c|c|}
\hline No. & \multicolumn{1}{|c|}{$\begin{array}{c}\text { Model / } \\
\text { Bentuk }\end{array}$} & Jumlah & $\%$ \\
\hline 1. & $\begin{array}{l}\text { Empat } \\
\text { persegi } \\
\text { panjang }\end{array}$ & 16 & 37,21 \\
\hline 2. & $\begin{array}{l}\text { Bujur } \\
\text { sangkar }\end{array}$ & 7 & 16,28 \\
\hline 3. & $\begin{array}{l}\text { Seperti huruf } \\
\text { U }\end{array}$ & 6 & 13,95 \\
\hline 4. & $\begin{array}{l}\text { Seperti huruf } \\
\text { L }\end{array}$ & 10 & 23,25 \\
\hline 5. & $\begin{array}{l}\text { Tidak } \\
\text { beraturan }\end{array}$ & 2 & 4,65 \\
\hline 6. & $\begin{array}{l}\text { Setengah } \\
\text { lingkaran }\end{array}$ & 1 & 2,33 \\
\hline 7. & $\begin{array}{l}\text { Melingkar / } \\
\text { lingkaran }\end{array}$ & 1 & 2,33 \\
\hline & \multicolumn{2}{|l|}{ objek } & $\mathbf{1 0 0} \%$ \\
\hline
\end{tabular}

Berdasarkan atas beberapa bentuk bungker seperti tersebut di atas dapat dibedakan menjadi dua berdasarkan letaknya, yaitu bungker yang ada di perbukitan dan bungker yang ada di dataran rendah. Secara umum dapat dikatakan bahwa bungker-bungker yang ada di dataran rendah menerapkan model atau bentuk yang sederhana atau tidak rumit. Bentuk yang sederhana ini meliputi empat persergi panjang, bujur sangkar, seperti huruf L. Sedangkan bungker-bungker yang ada di kawasan perbukitan menerapkan bentuk atau model seperti huruf $U$, tidak beraturan, setengah lingkaran, dan melingkar atau lingkaran. Namun demikian tidak berarti bahwa denah bentuk bujur sangkar dan empat persegi tidak diketemukan di kawasan perbukitan.

Dengan demikian timbul pertanyaan mengapa denah bentuk atau model seperti huruf $U$, tidak beraturan, setengah lingkaran, dan melingkar atau lingkaran yang secara teknis lebih sulit pembangunannya, dibuat di tempat yang sulit dijangkau yaitu kawasan 
perbukitan. Jawabannya adalah denah bentuk seperti itu dibuat dengan cara menyesuaikan lokasi atau menyesuaikan bentuk lahan yaitu bukit yang tidak rata. Dengan demikian bisa dimaklumi mengapa denah bentuk atau model seperti huruf $U$, tidak beraturan, setengah lingkaran, dan melingkar atau lingkaran terdapatnya hanya di kawasan perbukitan pantai selatan Kabupaten Lumajang dan Jember, Jawa Timur.

\section{Jangkauan Pengawasan Sarana Pertahanan Jepang}

Sasaran serangan sarana pertahanan Jepang yang dimaksud dalam subbab ini adalah pembuatan atau pendirian bungker Jepang yang "mulutnya" diarahkan ke sesuatu yang ada di depannya. Arah bungker Jepang ini sangat tergantung dari keberadaan pintu masuk. Dengan melihat letak pintu masuk akan dapat diketahui arah serangan orang-orang Jepang terhadap keberadaan lawannya. Pada umumnya pintu masuk bungker berlawanan arah dengan keberadaan tempat senjata yaitu senapan laras panjang dan meriam. Dengan melihat keberadaan tempat senjata tersebut akan diketahui arah sasarannya. Sasaran bungker Jepang yang ada di Kabupaten Lumajang dan Jember dapat diketahui berdasarkan tabel berikut.

\section{Kabupaten Lumajang}

Bungker Jepang yang ada di Kabupaten Lumajang seluruhnya berjumlah 26 objek. Dari jumlah tersebut arah sasaran bungker terbagi menjadi beberapa lokasi, yaitu:
Tabel 10. Arah sasaran bunker Jepang di Lumajang

\begin{tabular}{|c|c|c|c|}
\hline No & $\begin{array}{c}\text { Arah Sasaran } \\
\text { Bungker Jepang }\end{array}$ & Jumlah & $\%$ \\
\hline 1. & $\begin{array}{l}\text { Arah sasaran ke } \\
\text { laut } \\
\text { Lumajang }\end{array}$ & 22 & 84,62 \\
\hline 2. & $\begin{array}{l}\text { Arah sasaran } \\
\text { adalah jalan raya } \\
\text { Tempeh }\end{array}$ & 3 & 11,54 \\
\hline 3. & $\begin{array}{l}\text { Arah sasaran } \\
\text { tidak diketahui }\end{array}$ & 1 & 3,84 \\
\hline & & 26 objek & $\begin{array}{c}100 \\
\%\end{array}$ \\
\hline
\end{tabular}

\section{Kabupaten Jember}

Bungker Jepang yang ada di Kabupaten Jember seluruhnya berjumlah 17 objek. Dari jumlah tersebut arah sasarannya dapat dikelompokkan menjadi dua lokasi, yaitu:

Tabel 11. Arah sasaran bunker Jepang di Jember

\begin{tabular}{|c|l|c|c|}
\hline $\begin{array}{c}\mathbf{N} \\
\mathbf{0}\end{array}$ & \multicolumn{1}{|c|}{$\begin{array}{c}\text { Arah Sasaran } \\
\text { Bungker Jepang }\end{array}$} & $\begin{array}{c}\text { Jumla } \\
\mathbf{h}\end{array}$ & $\%$ \\
\hline 1. & $\begin{array}{l}\text { Arah sasaran ke laut } \\
\text { selatan Jember }\end{array}$ & 16 & $\begin{array}{c}94,1 \\
2\end{array}$ \\
\hline 2. & $\begin{array}{l}\text { Arah sasaran ke } \\
\text { jalan raya Kencong - } \\
\text { Puger }\end{array}$ & 1 & 5,88 \\
\hline & & $\begin{array}{c}\mathbf{1 7} \\
\text { objek }\end{array}$ & $\begin{array}{c}\mathbf{1 0 0} \\
\%\end{array}$ \\
\hline
\end{tabular}




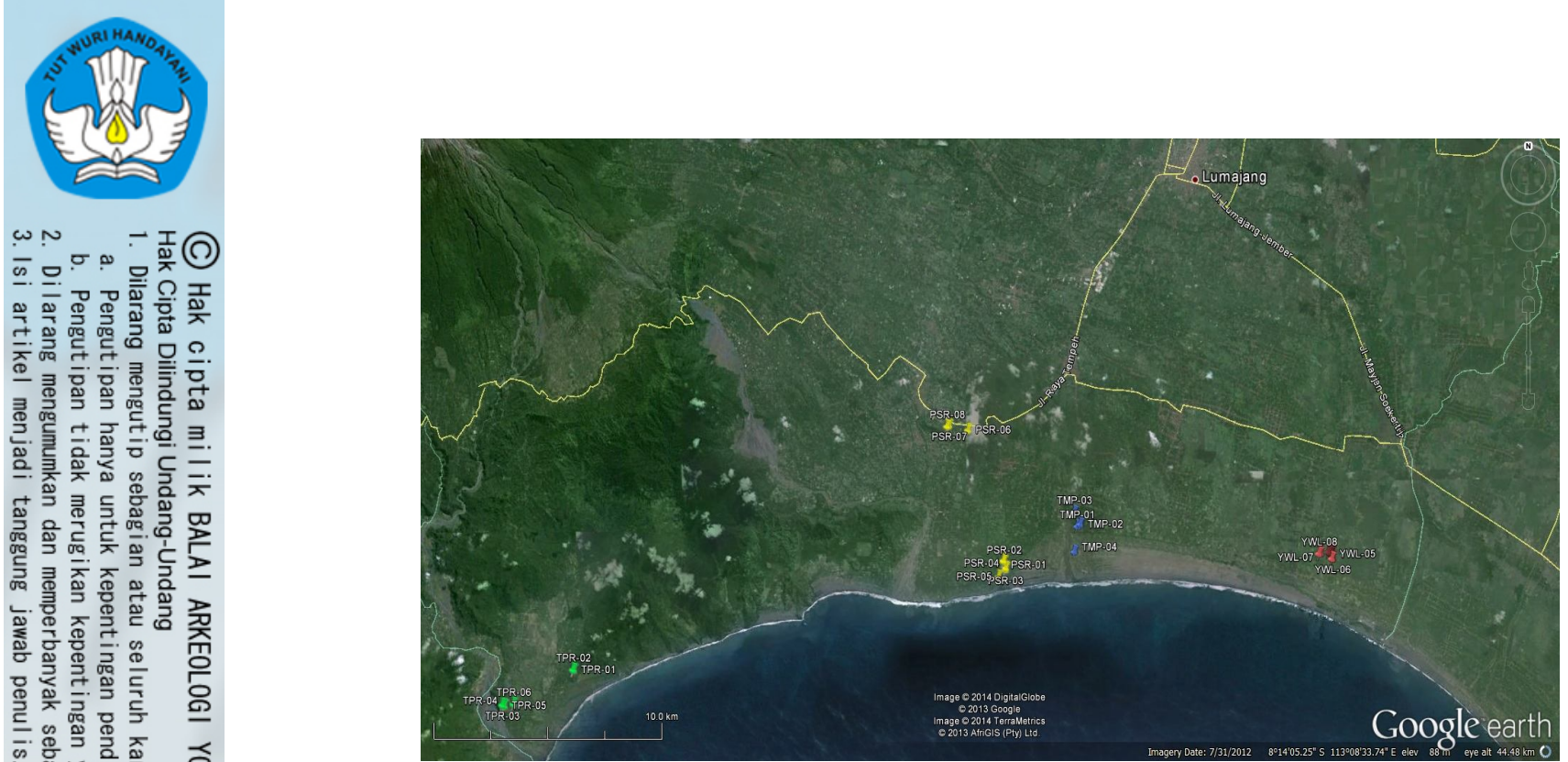

Gambar 15. Peta keletakan bungker Jepang di Kabupaten Lumajang memakai Google Earth

Dengan melihat kedua tabel (Kabupaten Lumajang dan Kabupaten Jember) tersebut di atas dapat diketahui bahwa sasaran utama serangan orang-orang Jepang adalah lalu lintas yang melewati laut. Seperti diketahui bahwa kedua daerah (Lumajang dan Jember) merupakan daerah yang kawasan bagian selatannya merupakan lautan (Samudera Indonesia). Bangsa Jepang kemungkinan berpikiran bahwa dengan menguasai kawasan pantai selatan kedua daerah tersebut akan dapat melanggengkan kekuasaannya di Jawa, khususnya di Lumajang dan Jember. Hal ini terlihat jelas dari peta keletakan bungker baik yang ada di Kabupaten Lumajang maupun Kabupaten Jember. Hal yang demikian ini (letak bungker berada di kawasan pantai) dapat dilihat dan dibandingkan dengan bungker-bungker sejenis yang ada di luar Indonesia. Salah satu contohnya adalah bungker yang ada di Pantai Perancis yang dibangun oleh Jerman pada sekitar tahun 1944. Di kawasan ini bungkerbungker tersebut dikenal dengan istilah Dinding Atlantik dan merupakan bangunan beton sebanyak 15000 yang terdiri atas 4000 bangunan besar dan 9300 bangunan kecil tempat peralatan artileri (Paul, 1975: 62). Keletakan yang demikian dapat dilihat dari peta-peta persebaran (Paul, 1975: 62 - 65) juga dari foto-foto (Paul, 1975: 76 - 87). Dari contoh tersebut dapat diketahui bahwa bungkerbungker buatan Jerman dibuat dari cor dan terletak di daerah pantai Perancis.

Terkait dengan hal tersebut di atas, keletakan yang demikian ini dapat dilihat dan disimak pada benteng-benteng pertahanan dari masa kolonial Belanda. Banyak benteng pertahanan yang dibuat oleh Belanda berada atau terletak pada tepi pantai. Sebagai contoh salah satunya adalah Benteng Lodewijk. Benteng ini terletak sekitar 200 meter di sebelah utara muara Sungai Cemara, tepat di tepi Selat Madura bagian ujung barat (Abbas, 2007: 5 dan Abbas, 2007a: 78). Contoh yang lain dapat dilihat pada buku Forts in Indonesia. Di dalam buku tersebut dipaparkan melalui gambar tentang benteng-benteng Belanda dan Portugis yang ada di 


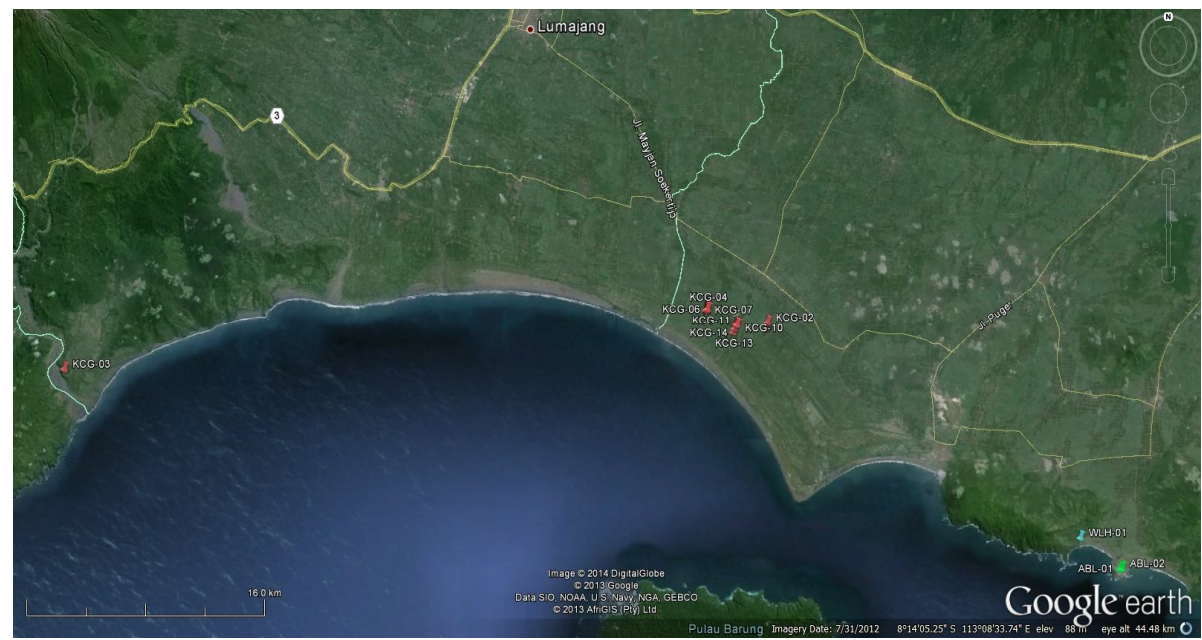

Gambar 16. Peta keletakan bungker Jepang di Kabupaten Jember memakai Google Earth

Indonesia Timur, khususnya di Sulawesi dan Maluku. Secara umum benteng-benteng asing yang ada di kedua pulau dan kepulauan di Indonesia Timur tersebut lokasinya berada di tepi pantai (Anonim, 2012: $166-275)$.

Selain jalan laut, urutan
kedua adalah jalan darat. Berdasarkan peta dari Google earth diketahui bahwa jalan darat yang menjadi amatan orang-orang Jepang di Lumajang dan Jember pada waktu itu berada di bagian utara kawasan pantai. Dengan adanya objek amatan yang berupa jalan darat di kedua daerah tersebut maka dibangunlah bungker Jepang. Bungker Jepang yang dibangun dalam rangka mengawasi lalu lintas darat di Kabupaten Lumajang ada tiga yaitu bungker Jepang PSR-06, PSR-07, dan PSR-08. Ketiga bungker Jepang ini secara administratif terletak di Dusun Pucarangga, Desa Condro, Kecamatan Pasirian. Sedangkan bungker Jepang yang juga dibangun untuk mengawasi lalu lintas darat di Kabupaten Jember hanya satu yaitu bungker Jepang KCG-03. Bungker ini secara administratif terletak di
Dusun Kedung Langkap, Desa Kraton, Kecamatan Kencong.

\section{PENUTUP}

\section{Kesimpulan}

Sesuai dengan hasil uraian di atas, dismpaikan beberapa kesimpulan sebagai berikut :

1. Seluruh tinggalan masa kolonial Jepang yang ada di Kabupaten Lumajang dan Kabupaten Jember, Jawa Timur dapat dikelompokkan menjadi tiga yaitu bungker sebanyak 40 objek, gua sebanyak 2 objek, dan tandon air atau tempat penampungan air sebanyak 1 objek.

2. Terdapat tujuh (7) tipe atau model tinggalan Jepang yaitu empat persegi panjang sebanyak 16 objek, bujur sangkar sebanyak 7 objek, seperti huruf $U$ sebanyak 6 objek, seperti huruf $L$ sebanyak 10 objek, tidak beraturan sebanyak 2 objek, setengah lingkaran sebanyak 1 objek, dan melingkar sebanyak 1 objek.

3. Bungker Jepang yang ada di Lumajang dan Jember sebagian besar diarahkan ke 
4. Ialu lintas air yaitu melalui laut selatan sebanyak 38 objek, diarahkan ke lalu lintas darat sebanyak 4 objek, dan tidak ada arah yang jelas sebanyak 1 objek.

\section{Saran dan Rekomendasi}

Peninggalan masa kolonial Jepang yang ada di Lumajang dan Jember merupakan cagar budaya sesuai dengan Undang-undang Republik Indonesia Nomor: 11 Tahun 2010 tentang Cagar Budaya. Sesuai dengan pengelolaan, cagar budaya pada umumnya dibagi menjadi dua yaitu pelestarian dan pemanfaatan. Sesuai dengan kebutuhannya, pengelolaan cagar budaya dimulai dari pelestarian. Pelestarian dilakukan dengan tujuan untuk memelihara objek beserta situsnya dengan berbagai cara agar dapat dimanfaatkan lebih lama dengan tetap memperhatikan dan mempertahankan makna kulturalnya (Subroto, 1997: 10 - 11 dan Subroto, 2003: 3 - 4). Kegiatan berikutnya adalah pemanfaatan. Meskipun peninggalan Jepang yang ada di Lumajang dan Jember tersebut belum ditetapkan sebagai cagar budaya, bangunan tersebut dapat dimanfaatkan sebagai objek dan daya tarik wisata (ODTW).

Melalui kegiatan penelitian tahun 2013 diketahui ada permasalahan yang cukup serius, yaitu terkait belum adanya kesadaran masyarakat akan tinggalan masa lampau yang ada di sekitar tempat tinggalnya. Hal ini dapat dilihat di Kabupaten Lumajang maupun di Kabupaten Jember. Di kedua kabupaten tersebut sisa-sisa kejayaan bangsa Jepang sangat tidak terurus dan cenderung terabaikan. Secara umum bungker Jepang ini belum dimanfaatkan, kecuali beberapa bungker oleh penduduk setempat dengan cara yang tidak pas. Pemanfaatan oleh penduduk sekitar objek adalah sebagai gudang keluarga, namun ada pula yang dimanfaatkan sebagai tempat sampah. Bahkan terdapat satu bungker yang keadaannya sangat memprihatinkan, yaitu tanah sekeliling tempat bungker telah dikeruk sedalam kurang lebih 1,5 meter. Dengan demikian bangunan bungker seolah-olah berdiri di atas batur yang tinggi. Bahkan ada yang lebih parah yaitu bungker telah dibongkar, yang tersisa hanya tinggal bagian fondasinya. Dengan kondisi yang demikian harus ada usaha nyata yang dilakukan untuk menanggulangi berbagai pemanfaatan yang tidak sesuai. Usaha ini seyogyanya dimulai dengan koordinasi antar pemangku kepentingan sebelum semuanya terlambat.

\section{UCAPAN TERIMAKSIH}

Karya tulis ini tidak akan mukin ada dan terwujud jika tidak ada bantuan dan kerjasama dari berbagai pihak. Oleh karena itu pada kesempatan ini penulis memberikan penghargaan dan ucapan terimakasih yang setinggi-tingginya kepada seluruh anggota tim penelitian dari Balai Arkeologi Yogyakarta yang tergabung dalam penelitian Sarana Pertahanan Jepang Pada Masa Perang Dunia II (Tahap IV). Ucapan terimaksih juga ditujukan kepada Radio Sentra di Lumajang; Dinas Pariwisata, Seni, dan Budaya Kabupaten Lumajang; Desa Wotgalih, Kecamatan Yosowilangun; Dinas Kebudayaan dan Pariwisata Kabupaten Jember; LSM Masyarakat Peduli Peninggalan Majapahit Timur di Lumajang; serta seluruh masyarakat di lokasi penelitian. 


\section{DAFTAR PUSTAKA}

Abbas, Novida. 2007. Laporan Penelitian Arkeologi, Penelitian Benteng Lodewijk Tahap II. Yogyakarta: Balai Arkeologi Yogyakarta.

. 2007a. Aktivitas Kehidupan Masa Lalu Di Dalam Benteng Lodewijk dalam Berita Penelitian Arkeologi No. 22. Yogyakarta: Balai Arkeologi Yogyakarta. Halaman: $76-85$.

Anonim. 1989. Ensiklopedi Nasional Indonesia. Jakarta: PT. Cipta Adi Pustaka.

Anonim. 2012. Forts in Indonesia. Jakarta: Kementerian Pendidikan dan Kebudayaan Republik Indonesia.

Kartodirdjo, Sartono (Editor Umum). 1976. Sejarah Nasional Indonesia VI. Jakarta: Departemen Pendidikan dan Kebudayaan.

Poerwadarminta, WJS. 1976. Kamus Umum Bahasa Indonesia. Jakarta: PN. Balai Pustaka.

Priswanto, Hery. 2015. Laporan Peninjauan Temuan Baru Struktur Bata Kuna Di Dusun Kedungsari, Desa Kedungmoro, Kecamatan Kunir, Kabupaten Lumajang, Propinsi Jawa Timur. Yogyakarta: Balai Arkeologi.

Rangkuti, Nurhadi. 2003. Pola Pemukiman Desa Masa Majapahit: Kajian Situs Arkeologi Di Kabupaten Lumajang, Jawa Timur dalam Berita Penelitian ArkeologiNo. 19. Yogyakarta: Balai Arkeologi.

Subroto, Ph. 1997. Kondisi Situs Trowulan dan Usaha-usaha Pelestariannya. Pacet: Sarasehan tentang Pelestarian Benda Cagar Budaya.

2003. Pemanfaatan Benda Cagar Budaya Bangunan Bata Pasca Pugar Untuk Kepentingan Pendidikan dan llmu Pengetahuan. Cisarua: Rapat Penyusunan Kebijakan Pemanfaatan Benda Cagar Budaya.

Undang-undang Republik Indonesia Nomor 11 Tahun 2010 tentang Cagar Budaya (CB).

Virilio, Paul. 1975. Bunker Archeology. New York: Princeton Architectural Press. 